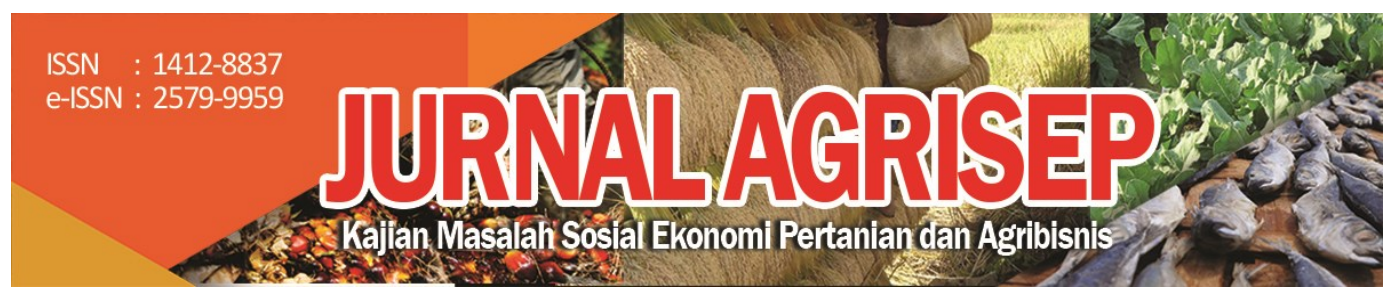

DOI: $10.31186 /$ jagrisep.20.2.421 - 441

\title{
STRATEGI PENGEMBANGAN MARKETING MIX DENGAN ANALISIS SWOT PADA GERAI KOPI LIBERIKA DI KABUPATEN TANJUNG JABUNG BARAT
}

The Development Strategy Of Marketing Mix With SWOT Analysis In The Liberika Coffee's Outlets in West Tanjung Jabung Regencygs

\author{
Dwi Nurul Amalia1) $\square$; Rozaina Ningsih'2) \\ 1,2)Program Studi Agribisnis, Fakultas Pertanian, Universitas Jambi, Jambi, \\ Indonesia \\ Email : amaliadwinurul@gmail.com
}

\begin{abstract}
The productivity of liberica coffee which continues to increase will increase opportunities for the development of liberica coffee agroindustry in Tanjung Jabung Barat Regency. One of the agro-industry efforts to maintain its existence in the business world, namely agro-industry must provide two types of benefits to consumers, namely functional and emotional benefits from products or services. One strategy to improve perceived quality is the application of the marketing mix. This study has the objectives of knowing 1) analyzing the implementation of the marketing mix at Liberika coffee outlets in Tanjung Jabung Barat Regency. 2) identify the marketing mix development strategy at Liberika coffee outlets in Tanjung Jabung Barat Regency. This study uses observation methods and survey methods to the field and see the conditions and potential of Liberika coffee outlets to be input and analysis. The results of research on the application of the marketing mix at Liberika coffee outlets indicate that in general Liberika coffee outlets have implemented a marketing mix strategy well. Liberika coffee outlets have improved perceived quality by implementing a good $7 P$ marketing mix (product, price, place, promotion, human resources, process and physical evidence). The Liberika coffee outlet development strategy is generated through a SWOT analysis. Based on the identification of internal and external factors, the strengths, weaknesses, opportunities and threats can be identified.
\end{abstract}

Keywords: agroindustry, liberica coffee, marketing mix, strategy 


\begin{abstract}
ABSTRAK
Produktivitas kopi liberika yang terus meningkat akan mengningkatkan peluang pengembangan agroindustri kopi liberika di Kabupaten Tanjung Jabung Barat. Salah satu upaya agroindustri untuk mempertahankan eksistensinya di dunia bisnis, yaitu agroindustri harus memberikan dua jenis manfaat kepada konsumen yaitu functional dan emotional benefit dari produk atau jasa. Salah satu strategi untuk meningkatkan perceived quality adalah penerapan marketing mix. Penelitian ini memiliki tujuan yaitu mengetahui 1) menganalisis implemetasi marketing mix pada gerai kopi liberika di Kabupaten Tanjung Jabung Barat. 2) mengidetifikasi strategi pengembangan marketing mix pada gerai kopi liberika di Kabupaten Tanjung Jabung Barat. Penelitian ini menggunakan metode observasi dan metode survey ke lapangan dan melihat kondisi dan potensi gerai kopi liberika untuk menjadi bahan masukan dan analisis. Hasil penelitian tentang penerapan marketing mix pada gerai kopi liberika menunjukkan bahwa secara umum gerai kopi liberika telah menerapkan strategi marketing mix dengan baik. Gerai kopi liberika telah meningkatkan perceived quality dengan menerapkan marketing mix (bauran pemasaran) 7P (produk, harga, tempat, promosi, SDM, proses dan bukti fisik) yang baik. Strategi pengembangan gerai kopi liberika dihasilkan melalui analisis SWOT. Berdasarkan hasil identifikasi faktor internal dan eksternal maka dapat diketahui kekuatan (strenght), kelemahan (weakness), peluang (opportunity) dan ancaman (threat).
\end{abstract}

Kata kunci: agroindustri, bauran pemasaran, kopi liberika, strategi

\title{
PENDAHULUAN
}

Komoditi Kopi adalah komoditi pertanian yang berperan strategis dalam ekonomi Indonesia. Peran komoditi kopi yaitu sebagai penghasil devisa, penyedia lapangan pekerjaan, serta penerimaan bagi petani dan pengelola perkebunan kopi maupun ekonomi pelaku lain yang terlibat pada aspek usahatani kopi, pengolahan, maupun pemasaran kopi. Indonesia adalah produsen kopi terbesar di dunia dengan total produksi tahun 2017 sebesar 668.677 ton naik hingga 674.636 ton di tahun 2018 (Direktorat Jenderal Perkebunan, 2019). Komoditi kopi adalah salah satu produk ekspor yang sangat potensial dalam menyumbang pendapatan negara selain sektor pertambangan dan sumberdaya mineral. Selain peluang ekspor yang semakin tinggi, peluang pemasaran kopi Indonesia memiliki tren meningkat setiap tahun. Salah satu varietas kopi yang dikembangkan di Provinsi Jambi adalah jenis kopi liberika yang bernama kopi tungkal liberika komposit. Potensi pengembangan kopi liberika antara lain kopi liberika merupakan kopi khas ditanam pada lahan gambut. Peningkatan produktivitas kopi liberika akan mengingkatkan peluang pengembangan agroindustri kopi liberika di Kabupaten Tanjung Jabung Barat.

Luas area kopi liberika di Kabupaten Tanjung Jabung Barat adalah 2.882 hektar pada tahun 2015 (BPS 2016. Pemasaran kopi liberika di Kabupaten 
Tanjung Jabung Barat secara umum masih konvensional. Berdasarkan penelitian Waluyo (2017) pemasaran kopi dimulai dari tingkat petani, kemudian didistribusikan oleh pedagang pengumpul yang dipasarkan ke ibukota Kabupaten Tanjung Jabung Barat. Dari Kuala Tungkal kemudian didistribusikan ke pedagang besar dan pengolah. Selain konsumen lokal terdapat jugakonsumen yang menjual ke luar negeri yakni ke Singapura serta Malaysia. Dilihat dari aspek demand, kopi ini memiliki permintaan yang besar, hal ini membutuhkan keratifitas secara khusus untuk menyesuaikan harga kopi tersebut. Petani liberika di Kabupaten Tanjung Jabung Barat menyatakan bahwa petani mengalami kesulitan dalam mencari pasar karena belum memperoleh dukungan berupa fasilitas dari pemerintah sehingga petani memasarkan kopi liberika dalam skala kecil dan terbatas dalam segi jaringan. Hal ini menyebabkan petani bersifat individu. Walaupun petani telah membentuk kelompok tani tetapi kinerja kelompok tani belum optimal. Disisi lain, varietas kopi liberika yang menjadi potensi unggulan daerah masuh belum dikenal oleh masyarakat umum (Hariyati dan Sumarno, 2013). Permasalahan tersebut memerlukan upaya untuk diperbaiki dalam pengembangan kopi liberika. Salah satu upaya dalam pengembangan kopi liberika yaitu adanya kerjasama petani dengan pihak eksternal sejak tahun 2014.

Peningkatan manajemen pemasaran produk melalui agroindustri salah satunya melalui gerai kopi liberika sebagai sentra pemasaran produk kopi liberika. Gerai kopi liberika mengelola pasca panen kopi liberika sesuai standar. Gerai kopi liberika memproduksi berbagai jenis olahan kopi yaitu berbentuk green bean/kopi biji, kopi sanggrai dan kopi bubuk. Pengembangan gerai kopi liberika dapat berjalan dengan baik atas partisipasi para stakeholders dan petani dalam memonitoring pengelolaan gerai secara berkala. Secara umum permintaan kopi liberika saat ini sedang mengalami peningkatan. Peningkatan ini sejalan dengan perubahan gaya hidup masyarakat, sehingga masyarakat memiliki berbagai pilihan dalam mengkonsumsii kopi sesuai dengan selera konsumen.

Saat ini masyarakat Indonesia memiliki gaya hidup yang modern, salah satunya adalah masyarakat banyak yang mengkonsumsi olahan kopi setiap harinya. Kopi dapat dikonsumsi berbagai lapisan masyarakat baik masyarakat dalam golongan remaja maupun dewasa bahkan orang tua. Apabila dilihat dari sisi ekonomi, konsumen kopi olahan bukan hanya dari masyarakat perkotaan saja tapi juga masyarakat yang tinggal di pedesaan (Retnowati dan Putra, 2017). Hal tersebut berpengaruh singnifikan bagi permintaan kopi liberika. Di sisi lain fenomena tersebut dapat menimbulkan kompetisi antara para produsen kopi lahan terutama kopi liberika. Salah satu upaya produsen olahan kopi liberika menghadapi persaingan yaitu para pelaku usaha atau industri harus memberikan keuntungan atau benefit bagi konsumen. Keuntungan tersebut terdiri dari dua jenis yang pertama adalah functional benefit atau keuntungan 
secara fungsi dan juga keuntungan secara emosi atau emotional benefit. Functional benefit adalah tingkat kepuasan yang diterima oleh konsumen atas barang maupun jasa yang sudah diterima sesuai dengan keinginan konsumen Sedangkan emotional benefit adalah nilai atau manfaat yang ditawarkan perusahaan atau sesuatu yang mampu diberikan perusahaan atau unit usaha sesuai dengan pelayanan dan fasilitas yang mereka tawarkan sehingga memiliki kesan positif atau memberikan keuntungan bagi konsumen (Anderson, 1994).

Functional benefit dan emotional benefit dapat diterapkan pada strategi marketing mix pada bidang jasa, yakni produk, harga, tempat, promosi, SDM, proses dan bukti fisik (Kotler dan Armstrong, 2001). Setiap usaha harus merancang strategi marketing mix sebelum mengembangkan usahanya (Hernanto, 1991). Strategi marketing mix meliputi product, place, price, people, process, physical evidence dan promotion. Gerai kopi liberika dalam menerapkan strategi marketing mix yakni menjual berbagai macam olahan kopi liberika. Marketing mix merupakan strategi yang mampu meningkatkan jumlah penjualan produk perusahaan (Nurcahyo dan Wahyuati, 2017). Khulud dan Arifin (2016), Nasution et al., (2017), Nurman et al., (2020) menunjukkan strategi marketing mix merupakan ukuran untuk meningkatkan volume pemasaran. Tujuan yang disusun dalam penelitian ini untuk 1) menganalisis implemetasi marketing mix pada gerai kopi liberika di Kabupaten Tanjung Jabung Barat. 2) mengidetifikasi strategi pengembangan marketing mix pada gerai kopi liberika di Kabupaten Tanjung Jabung Barat.

\section{METODE PENELITIAN}

Survey dilakukan di Gerai kopi liberika Kabupaten Tanjung Jabung Barat. Lokasi diipilih secara sengaja (purposive sampling) dengan alasan bahwa Gerai kopi liberika merupakan gerai terbesar yang menjual hasil produksi agroindustri kopi liberika. Lokasi ini merupakan sentra penjualan kopi liberika dalam bentuk olahan di Desa Mekar Jaya. Desa Mekar Jaya adalah daerah sentra produksi kopi liberika di Kabupaten Tanjung Jabung Barat. Data yang diperoleh meliputi data primer dan data sekunder. Pengumpulan data dilakukan melalui wawancara terstruktur menggunakan kuisioner dan wawancara indepth interview dengan sejumlah responden (Soekartawi, 2011). Data sekunder dihimpun melalui data dokumen, jurnal terkait yang diperoleh dari instansi terkait maupun survey lapangan yang berhubungan dengan penelitian ini (Sekaran, 2006). Lokasi Gerai kopi liberika beralamat di Kelurahan Mekar Jaya, Kecamatan Betara Tanjung Jabung Barat Provinsi Jambi.

424 | Rozaina Ningsih, Dwi Nurul Amalia; Strategi Pengembangan Kopi... 


\section{HASIL DAN PEMBAHASAN}

\section{Penerapan marketing mix pada agroindustri kopi liberika}

Marketing mix menurut Kotler (2001) adalah indikator variabel yang digunakan perusahaan untuk mencapai tujuan pemasarannya dalam sasarannya. Adapun variabel yang digunakan untuk mengetahui proses bauran pemasaran yang dilakukan oleh gerai kopi liberika yang 7P yaitu produk, harga, tempat, promosi, SDM, proses and bukti fisik. Peningkatan produktivitas kopi liberika akan mengingkatkan peluang pengembangan gerai kopi liberika di Kabupaten Tanjung Jabung Barat. Salah satu upaya agroindustri untuk mempertahankan eksistensinya di dunia bisnis, yaitu agroindustri harus memberikan dua jenis manfaat kepada konsumen yaitu yaitu functional dan emotional benefit dari produk maupun jasa.

\section{Produk (product)}

Kegiatan pemasaran produk harus memiliki suatu sistem manajemen yang baik (Suratiyah, 2009). Guna mencapai tujuan tertentu secara efektif dan efisien. Begitu juga dalam perihal penjualan produk kopi liberika di gerai kopi liberika. Manajemen pemasaran kopi liberika di gerai kopi liberika menjadi suatu gambaran bagaimana perkembangan kualitas dan kuantitas dari kopi Liberika. gerai kopi liberika juga melakukan pemasaran produk secara online maupun offline. Secara online, pengurus gerai kopi liberika melakukan pemasaran melalui sosial media dengan memposting pada suatu kegiatan atau event tertentu atau menunjukkan keadaan gerai kopi liberika yang ramai akan pengunjung. Secara offline, dengan cara menyebarluaskan informasi dari mulut ke mulut, memperkenalkan produk dengan mengikuti sebuah kegiatan pameran, perlombaan, kegiatan kopi dan sebagainya.

Pemasaran kopi liberika melalui gerai dikelola oleh pengurus gerai kopi liberika. Gerai kopi liberika memperoleh bahan baku kopi liberika dari petani yang mengusahakan kopi yang sudah sesuai dengan standar operasional produk dan manajemen produk yang baik. Pada saat ini, gerai kopi liberika menjual beberapa merek kopi yang berbeda tetapi terdapat juga satu merk yang sama tapi diproses dengan cara berbeda misalnya kopi bentuk biji ada juga yang dijual dengan kopi bentuk bubuk. Berikut disajikan data penjualan pada gerai kopi liberika yang terlihat pada tabel 1.

Tabel 1 menggambarkan data produk kopi liberika yang terjual selama bulan Januari s/d September 2020 dengan berbagai merek yang dihasilkan oleh petani. Ada beberapa jenis merk kopi yang ditampung gerai kopi liberika yaitu Paristo Original, Rosbean Liberika, Liberika Tungkal Jambi, Luwak Kembar, Luwak original, Kopi Ajib, Kopi Jempol dan Jempol Liberco. Pada kolom penjualan perhari adalah data penjualan produk kopi dalam satu hari yaitu dengan cara mentotalkan semua jumlah produk merek kopi yang terjual dalam satu bulan 
kemudian dibagi 30 hari sehingga diperoleh hasil rata-rata penjualan produk kopi dalam satu hari. Hasil penelitian pada aspek produk dalam strategi pemasaran menyatakan pada kriteria produk gerai kopi liberika secara umum merupakan produk yang berkualitas, produk yang mudah dikenali, kemasan yang menarik dan cita rasa yang sesuai selera.

Tabel 1. Penjualan Kopi Liberika yang Dijual Melalui Penjualan Produk Kopi di Gerai kopi liberika, Bulan Oktober 2020

\begin{tabular}{lcrrrrrrrr}
\hline & \multicolumn{8}{c}{ Produk Kopi (pcs } \\
\cline { 2 - 10 } Bulan & $\begin{array}{c}\text { Paristo } \\
\text { Original }\end{array}$ & $\begin{array}{c}\text { Rosbean } \\
\text { Liberika }\end{array}$ & $\begin{array}{c}\text { Liberika } \\
\text { Tungkal } \\
\text { Jambi }\end{array}$ & $\begin{array}{c}\text { Luwak } \\
\text { Kembar }\end{array}$ & $\begin{array}{c}\text { Luwak } \\
\text { Original }\end{array}$ & $\begin{array}{c}\text { Kopi } \\
\text { Ajib }\end{array}$ & $\begin{array}{c}\text { Kopi } \\
\text { Jempol }\end{array}$ & $\begin{array}{c}\text { Liberco } \\
\text { Penjualan } \\
\text { Perhari } \\
\text { (Pcs/hari) }\end{array}$ \\
\hline Jan & 150 & - & 10 & - & 11 & - & 25 & - & 6,5 \\
Feb & 274 & - & 27 & 17 & 33 & - & 32 & 54 & 14,5 \\
Mar & 115 & 50 & 43 & 6 & 36 & - & 21 & 34 & 10 \\
Apr & 613 & 3 & 24 & 5 & 25 & - & 4 & 15 & 23 \\
Mei & 129 & 8 & 4 & 9 & 48 & - & 6 & 14 & 7 \\
Jun & 471 & 15 & 5 & 33 & 25 & - & - & - & 18 \\
Jul & 237 & 40 & 27 & 59 & 49 & 15 & - & - & 14 \\
Agt & 161 & 10 & 23 & 37 & 19 & 24 & - & - & 9 \\
Sep & 185 & 117 & 37 & 34 & 62 & 30 & - & - & 15,5 \\
Total & 2.335 & 243 & 200 & 200 & 308 & 69 & 88 & 117 & \\
\hline
\end{tabular}

Sumber: Hasil pengolahan data (2020)

\section{Harga (price)}

Harga merupakan elemen bauran pemasaran yang menganalisis pendapatan dan yang paling dinamis dibandingkan dengan elemen lainnya dengan mempertimbangkan ukuran biaya, kurva permintaan pelanggan, dan harga pesaing (Zeithaml, 1988). Pada gerai kopi liberika metode penetapan harga adalah suatu harga yang terletak diantara harga yang terlalu rendah untuk menghasilkan laba dan harga yang terlalu tinggi untuk menghasilkan cukup permintaan (Kotler, 2001). Jenis olahan kopi liberika beserta harganya terlihat pada Tabel 2.

Dari tabel 2, untuk harga kopi dengan jenis olahan terdapat grade I, II dan ,III/IV. Grade I adalah struktur ukuran biji kopi yang kecil dam paling baik kualitasnya karena keseragaman ukuran biji kopi sedangkan grade II kualitas sama baik namun struktur ukuran biji yang tidak seragam, dominan biji yang kecil dan sedikit ukuran besar sehingga tidak sama dari segi ukuran. Grade III/IV mempunyai kualitas sama baik, namun untuk segi ukuran tidak seragam dan campur dari biji yang ukurannya kecil dan ukuran yang besar sama dominan. Dengan perbedaan grade di atas mempengaruhi harga biji kopi yang akan dijual.

426 | Rozaina Ningsih, Dwi Nurul Amalia; Strategi Pengembangan Kopi... 
Pada jenis olahan kopi roasted dan kopi bubuk tersedia dalam berbagai jenis ukuran kemasan tergantung berat /isi. Aspek harga dalam strategi pemasaran yang diperoleh dari konsumen menyatakan pada kriteria harga Gerai kopi liberika secara umum merupakan harga produk sesuai kualitas, harga produk terjangkau, tersedia daftar harga, dan adanya diskon/potongan.

Tabel 2. Jenis Olahan dan Harga Kopi Liberika yang di Gerai kopi liberika

\begin{tabular}{ccrrrrr}
\hline \multirow{2}{*}{ No. } & \multicolumn{2}{c}{ Biji Kopi } & \multicolumn{2}{c}{ Roasted } & \multicolumn{2}{c}{ Powder } \\
\cline { 2 - 7 } & Grade & Harga/Kg & Berat $(\mathrm{Kg})$ & Harga & Berat $(\mathrm{Kg})$ & \multicolumn{1}{l}{ Harga } \\
\hline 1 & I & 140.000 & 1,00 & 230.000 & 1,00 & 250.000 \\
2 & II & 130.000 & 0,50 & 120.000 & 0,50 & 135.000 \\
3 & III/IV & 110.000 & 0,25 & 70.000 & 0,25 & 80.000 \\
4 & & & 0,20 & 60.000 & 0,20 & 65.000 \\
5 & & & & & 0,10 & 30.000 \\
6 & & & & & 0,05 & 20.000 \\
\hline
\end{tabular}

Sumber: Hasil pengolahan data (2020)

\section{Tempat (place)}

Tanjung Jabung Barat merupakan kabupaten yang menjadi sentra produksi kopi liberika di wilayah Provinsi Jambi. Berdasarkan kondisi agroklimat sebagian besar lahannnya merupakan lahan gambut, hal ini merupakan kondisi yang cocok ditanami kopi liberika. Karena kopi liberka mampu tumbuh di dataran rendah, lebih mudah beradaptasi pada kondisi cuaca, serangan hama atau penyakit, serta dapat beradaptasi dengan baik terhadap kondisi lahan yang kurang subur. Tradisi menanam kopi yang telah puluhan tahun pada masyarakat Betara, kemudian banyaknya kebun kopi liberika khususnya di Kelurahan Mekar Jaya dalam kegiatan pengembangan kopi rantai usaha mulai dari pembibitan, budidaya kopi dalam bentuk perkebunan sampai pada Unit Pengolahan Hasil (UPH) kopi liberika yang mengolah pasca panen biji kopi liberika merupakan tradisi masyarakata di Kecamatan Betara sebagai mata pencaharian masyarakat yang berprofesi sebagai petani.

Gerai kopi liberika berdiri sejak tanggal 30 Oktober tahun 2017. Gerai ini dibentuk melalui dana program bantuan kemitraan dari perusahaan yaitu PetroChina. Program tersebut bertujuan untuk membentuk suatu sentra pemasaran dan juga sentra promosi kopi liberika. Program kemitraan ini berkembang dengan baik karena adanya dukungan dari instansi di Kabupaten Tanjung Jabung Barat yaitu badan perencanaan dan Pembangunan Daerah atau Bappeda, Dinas Koperasi Perindustrian dan Perdagangan atau Diskoperindag, Dinas pertanian serta Dinas Perkebunan. Dukungan ini menjadi motivasi yang 
tinggi bagi gerai kopi liberika untuk terus berkembang dan berinovasi dalam memasarkan produk kopi liberika. Hal ini dikarenakan pemasaran kopi liberika memiliki potensi yang sangat baik jika dikelola dengan manajemen yang baik. Hasil penelitian menunjukkan pada aspek place atau tempat terlihat dari adanya gerai kopi liberika di Kelurahan Mekar Jaya, konsumen dengan mudahmengkonsumsi olahan kopi liberika karena lokasi ini merupakan lokasi yang strategis, mudah dijangkau, dekat dengan akses jalan raya, memiliki parkiran yang memadai, bangunan yang sangat menarik serta terjaga kebersihannya.

\section{Promosi (promotion)}

Perusahaan perlu melakukan promosi dalam memasarkan atau memperkenalkan suatu produk sehingga akan dapat menginformasikan produk yang dimiliki perusahaan kepada konsumen (Tjiptono, 2000). Gerai kopi liberika di Kelurahan Mekar Jaya merupakan suatu bentuk tindakan lanjutan dari CSR Perusahaan PetroChina International Jabung Ltd yang berorientasi kepada program sustainable agriculture yang memfokuskan kopi liberika sebagai objek sasaran di Desa Mekar Jaya Kecamatan Betara Kabupaten Tanjung Jabung Barat. Gerai kopi liberika ini menjadi tumpuan sebagai bentuk implementasi keseriusan berjalannya program CSR dalam hal mengembangkan agroindustri kopi Liberika. Gerai kopi liberika memasarkan produk dengan penggunaan gedung yang terbuat dari papan dan kayu yang berbentuk rumah tradisional dan disesuaikan dengan keadaan alam sekitar yang masih banyak areal perkebunan kopi dan pinang namun dikemas dengan konsep yang modern.

Gerai kopi liberika kopi Liberika menjadi wadah dalam proses pemasaran kopi Liberika yang dihasilkan oleh petani serta produk turunan kopi liberika lainnya gerai kopi liberika juga melakukan pemasaran produk secara online maupun offline. Secara online, pengurus Gerai kopi liberika melakukan pemasaran dan promosi melalui sosial media dengan membagikan secara online pada suatu kegiatan atau event tertentu atau menunjukkan keadaan Gerai kopi liberika yang ramai akan pengunjung. Secara offline, dengan cara menyebar luaskan informasi dari mulut ke mulut, memperkenalakan produk dengan mengikuti sebuah kegiatan pameran, perlombaan, kegiatan kopi dan sebagainya. Hasil penelitian pada aspek promotion (promosi) dalam strategi pemasaran yang diperoleh dari konsumen menyatakan pada kriteria promosi gerai kopi liberika secara umum adalah banyaknya iklan atau promosi, adanya event atau pameran yang diselenggarakan, diskon produk saat event atau pameran dan ketersediaan online shop. Perbedaan promosi kopi liberika dengan kopi lainnya adalah promosi kopi lebih intensif dibandingkan dengan jenis kopi lainnya karena jenis kopi ini belum terlalu populer dikalangan masyarakat. Oleh karena itu, pihak produsen berupaya meningkatkan sistem pemasaran secara langsung maupun tidak lansung.

428 | Rozaina Ningsih, Dwi Nurul Amalia; Strategi Pengembangan Kopi... 


\section{Orang (people)}

Bagian dari orang yang terlibat dalam strategi pemasaran antara lain adalah karyawan, konsumen gerai, dan konsumen lain dalam lingkungan gerai. Variabel orang atau sumber daya manusia (SDM) memiliki dua karakteristik, yaitu pelayanan kepada konsumen dan orang lain. Sistem rekrutmen pada gerai kopi liberika tidak membutuhkan syarat khusus. Sehingga dapat dikatakan bahwa SDM dalam gerai kopi liberika ini dalam kategori cukup. Perihal menjalankan sebuah roda kepengurusan, dalam hal ini gerai yang berbentuk badan usaha pengelola dari koperasi Mekar Sejahtera Mandiri memiliki struktural pengelola yang baik guna untuk melanjutkan kegiatan operasional dari gerai kopi liberika yang telah berdiri. Gerai kopi liberika yang posisinya merupakan badan usaha pengelola dari koperasi, memiliki peranan dan pertanggung jawabanya sendiri. Dari segi internal, gerai berhak melakukan kegiatan operasional yang selama pelaksanaan tidak melenceng ataua melanggar peraturan dari koperasi. Tetapi jika ada sesuatu masukan atau dari pihak pengurus ingin berencana mengembangkan sesuatu dari gerai harus melalui sepengetahuan pihak koperasi dan dari keputusan musyawarah anggota.

Ketua pengurus gerai kopi memiliki peranan penting didalam menjalankan kegiatan operasional dengan memberi komandi kepada semua anggota, ketua harus dituntut untuk mengetahui keadaan di semua lini usaha. Begitu juga dengan sistem manajemen yang di terapkan untuk kegiatan operasional gerai. Sebuah sistem manajemen sangat menentukan bagaimana efektifitas dan efesiensi sebuah usaha itu berjalan. Meskipun gerai saat ini belum bertujuan ke arah profit oriented, sebaiknya sebuah manajemen atau tata kelola harus diterapkan untuk memudahkan dalam sistem pengerjaan dan menspesifikasikan sebuah kerjaan agar bisa mencapai sebuah tujuan dengan efektif. Hasil penelitian pada aspek SDM dalam strategi pemasaran yang diperoleh dari konsumen menyatakan bahwa secara umum penampilan karyawan menarik, perilaku karyawan yang ramah dan adanya empati kepada konsumen.

\section{Proses (process)}

Proses pemasaran kopi liberika adalah hal yang cukup sulit dilakukan di Kecamatan Betara, hal ini dikarenakan terlalu banyak merk kopi yang beredar di pasaran namun, pemerintah daerah dan pemerintah provinsi bekerja sama untuk menselaraskan produk kopi Liberika bermacam merk tersebut dengan logo perahu layar bertuliskan Kopi Liberika Tungkal Jambi, inilah yang menjadi solusi agar pemasaran lebih mudah dikenal dalam satu induk yaitu kelompok MPIG dan tentunya diolah sesuai SOP. Dengan adanya proses pengolahan kopi Liberika di Kecamatan Betara, beberapa kelompok tani menghasilkan produk berbentuk kemasan dengan berbagai Merk dan Jenis dapat dilihat pada Tabel 3. 
Tabel 3. Kelompok Tani/Petani yang Menghasilkan Produk Kopi dengan Merk Kopi Liberika di Kecamatan Betara

\begin{tabular}{lll}
\hline No. & \multicolumn{1}{c}{ Merk Kopi Liberika } & \multicolumn{1}{c}{$\begin{array}{c}\text { Kelompok Tani yang } \\
\text { Memproduksi }\end{array}$} \\
\hline 1 & Paristo & Paristo \\
2 & Liberika Tungkal Jambi & Banyu Mili \\
3 & Luwak Kembar & Supadi (Non Kelompok Tani) \\
4 & Luwak Original & Sri Utomo II \\
5 & Kopi Ajib & Firdaus (Non Kelompok tani) \\
6 & Kopi Jempol Liberco & Sidomuncul \\
\hline
\end{tabular}

Sumber: Hasil pengolahan data (2020)

Tabel di atas menunjukkan bahwa ada 6 merk Kopi Liberika yang ada di Kecamatan Betara dengan pengelolaan kelompok tani yang berbeda. Masingmasinng merk kopi sudah bersertifikasi MPIG (Masyarakat Perlindungan Indikasi Geografis). Dari beberapa merk kopi Liberika, masih ada merk kopi yang tidak bersertifikasi MPIG namun tetap dikelola secara SOP. Hal ini disebabkan karena kelompok yang tidak tergabung dalam kelompok MPIG. Kelompok tani yang tidak bergabung dalam MPIG ini memiliki alasan karena tidak memiliki visi dan misi yang sama, dan ketika proses wawancara dengan pertanyaan yang lebih mendalam, petani enggan untuk memberikan alassan yang lebih jauh mengapa merek tidak bergabung dalam Kelompok MPIG. Hasil penelitian pada variabel proses dalam strategi pemasaran, konsumen menyatakan pada kriteria proses, gerai kopi liberika secara umum memiliki kualitas bahan baku yang baik,tersedia jasa delivery dan COD, desain tata letak produk yang selalu berganti dan variasi desain atau jenis yang dijual.

\section{Bukti fisik (physical evidence)}

Gerai kopi liberika mekar jaya yang juga dikenal dengan Gerai Meja, merupakan singkatan dari Gerai Mekar Jaya, nama lokasi gerai berada. Gerai meja didesain seperti warung kopi atau café dengan menampilkan bangunan kayu yang berarsitektur local. Lokasi gerai berada di tepi jalan utama, sehingga mudah dicapai dan disinggahi, posisilokasi strategis sebagai calon koridor utama tempat wisata. Sebagai teras wisata, gerai telah memiliki bangunan dan elengkapan untuk menerima kunjungan pelancong. Gerai saat ini adalah tempat untuk melakukan penjualan minum dan makanan berbasis kopi serta hasil usaha masyarakat di sekeliling gerai, baik itu berupa minuman kopi, kerupuk, pisang rebus, mie rebus dan mie kuah. Selain itu dijual berbagai bubuk kopi liberika hasil dari kopi liberika setempat dengan berbagai merk seperti; Paristo, Liberco, Liberika Tungkal Jambi, Kopi Ajib, Kopi Luwak Kembar dan Jempol 
dan juga dijual souvenir seperti baju kaos bertema kopi. Untuk minuman kopi yang dijual dan diseduh dengan cara yang sudah kekinian. Menu yang ditawarkan seperti kopi saring V60, Aeropress, Espresso, Cappucino dan varian lainnya sudah tersedia di Gerai Meja. Variabel bukti fisik dalam strategi pemasaranecara umum memiliki desain bangunan yang menarik, kenyamanan dalam berkunjung dan berbelanja, penataan produk yang sesuai dan tersedia musik dalam gerai.

\section{Strategi pengembangan marketing mix dengan analisis SWOT}

Strategi dalam suatu kegiatan pemasaran adalah salah satu alat untuk memperoleh tujuan yang telah disusun Markus (2002). Strategi adalah suatu proses atau cara penentuan target yang dilakukan oleh para pimpinan dengan fokus pada ada planning jangka panjang suatu perusahaan. Strategi memiliki beberapa langkah atau aturan yang disusun agar tujuan yang yang telah ditentukan bisa tercapai dengan optimal. Dalam penelitian ini dilakukan analisis tentang faktor internal eksternal dan faktor internal Adapun faktor internal dalam gerai kopi liberika antara lain faktor manajemen dan juga strategi penentuan produk. Faktor tersebut dianalisis dengan menggunakan analisis SWOT yang hasilnya akan digunakan sebagai bahan penentuan strategi pemasaran dalam gerai kopi liberika. Strategi yang telah disusun menggunakan pendekatan bauran pemasaran atau marketing mix meliputi terciptanya produk yang inovatif yang sesuai dengan kebutuhan konsumen, harga yang bersaing, promosi yang lebih menarik dan dapat dijangkau oleh konsumen, lokasi penjualan yang dekat dengan pemukiman. Faktor ini memiliki tujuan untuk mempermudah konsumen dalam menjangkau produk yang tersedia pada gerai kopi liberika. Apabila konsumen mudah untuk menjangkau dan sering berkunjung ke gerai kopi liberika, maka penjualan atau pemasaran di gerai tersebut akan meningkat secara signifikan dan keuntungan akan diperoleh secara optimal. Kumpulan dari faktor strategis internal gerai kopi liberika di Kelurahan Mekar Jaya terlihat pada tabel IFAS berikut.

Terlihat pada tabel IFAS, Adapun faktor strategis dari indikator kekuatan dan kelemahan diperoleh dari informasi dan wawancara dengan beberapa informan yaitu pengelola gerai kopi liberika, instansi terkait, serta konsumen yang membeli kopi olahan di gerai kopi liberika. Total nilai kekuatan yaitu 1,150 yang merupakan gambaran nilai faktor strategis dengan menggunakan analisis Marketing Mix 7P Yaitu harga, produk, tempat, promosi, proses, sumber daya manusia dan bukti fisik.

Berdasarkan tabel IFAS, indikator ini memiliki skor yaitu lebih besar dari 0,325 . Nilai ini jika dibandingkan dengan nilai kelemahan yang memiliki total skor sebesar 0,700 yang terdiri dari beberapa faktor strategis antara lain promosi, sistem produksi, desain produk, jenis produk, manajemen hingga lokasi penjualan yang digunakan oleh gerai kopi liberika. selanjutnya faktor strategis 
eksternal dari gerai kopi liberika tersaji dalam tabel EFAS berikut. Terlihat pada tabel EFAS, faktor strategis dari indikator peluang dan ancaman yang diperoleh dari informasi melalui informan. Dalam penelitian ini informan tersebut antara lain ahli yang berkompeten dibidangnya, persaingan usaha yang sejenis, instansi terkait dan masyarakat sebagai konsumen yang membeli produk gerai kopi liberika. Konsumen produk kopi liberika juga merupakan mitra dari perusahaan dalam bentuk program tanggung jawab perusahaan (CSR). Kemitraan juga dilakukan dengan pihak akademisi antara lain adalah dengan Universitas Jambi

\section{Tabel 4. Penentuan IFAS}

\begin{tabular}{|c|c|c|c|c|c|}
\hline \multicolumn{6}{|c|}{ Internal factor analysis summary (EFAS) } \\
\hline \multirow{9}{*}{ 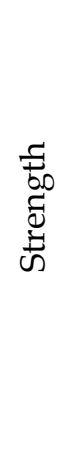 } & \multicolumn{2}{|c|}{ Faktor strategis } & \multirow[t]{2}{*}{ Bobot } & \multirow[t]{2}{*}{ Rating } & \multirow[t]{2}{*}{ Skor } \\
\hline & & Lokasi Penelitian (Kecamatan Betara) menjadi & & & \\
\hline & 1 & Sentra Produksi Kopi Liberika di Provinsi & 0,100 & 5 & 0,500 \\
\hline & & Jambi & & & \\
\hline & 2 & $\begin{array}{l}\text { Gerai Kopi Liberika sebagai Tempat } \\
\text { Pemasaran dan Promosi }\end{array}$ & 0,050 & 3 & 0,150 \\
\hline & 3 & Kopi Liberika Tersertifikasi Indikasi Geografi & 0,050 & 4 & 0,200 \\
\hline & 4 & Ketersediaan Bahan Baku & 0,150 & 4 & 0,600 \\
\hline & 5 & Memiliki Sarana dan prasarana penunjang & 0,250 & 5 & 1,250 \\
\hline & & Sub total & & & 2,700 \\
\hline \multirow{7}{*}{ 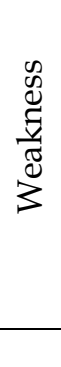 } & \multicolumn{2}{|c|}{ Faktor strategis } & Bobot & Rating & Skor \\
\hline & 1 & Belum Mampu memenuhi permintaan Pasar & 0,200 & 5 & 1,000 \\
\hline & 2 & Kurangnya Penerapan SOP & 0,025 & 4 & 0,100 \\
\hline & 3 & $\begin{array}{l}\text { Penjualan Kopi Liberika Dilakukan Secara } \\
\text { Individu, belum Bersinergi }\end{array}$ & 0,150 & 4 & 0,600 \\
\hline & 4 & Keterbatasan Modal Petani & 0,025 & 5 & 0,125 \\
\hline & \multicolumn{2}{|r|}{ Sub total } & & & 1,825 \\
\hline & & Total & 1,00 & & 0,700 \\
\hline
\end{tabular}

Sumber: Hasil pengolahan data (2020)

Kemitraan ini ini memberikan dampak yang positif. Hal ini terlihat dengan peningkatan permintaan yang terjadi pada beberapa periode terakhir. Berdasarkan tabel EFAS, indikator yang memiliki skor yang cukup besar yaitu sebesar 0,350 adalah nilai opportunity atau peluang. Sedangkan nilai ancaman atau threat memiliki total skor sebesar 0,075. Nilai ini merupakan gambaran dari beberapa faktor strategis yaitu adanya produk lain yang sejenis yang merupakan persaingan bagi produk kopi liberika, terjadinya alih fungsi lahan, serta adanya serangan hama dan penyakit yang menyerang tanaman kopi liberika. Hasil perhitungan total faktor strategis pada gerai kopi liberika yang dihitung berdasarkan faktor internal dan eksternal pada tabel IFAS dan EFAS, kemudian dilakukan analisis dan sintesis, maka perhitungan tersebut dikonversi ke dalam matriks dengan 4 indikator SWOT.

432 | Rozaina Ningsih, Dwi Nurul Amalia; Strategi Pengembangan Kopi... 


\section{Tabel 5. Penentuan EFAS}

\begin{tabular}{|c|c|c|c|c|c|}
\hline \multicolumn{6}{|c|}{ External factor analysis summary (EFAS) } \\
\hline \multirow{5}{*}{ 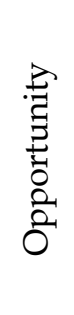 } & \multicolumn{2}{|c|}{ Faktor strategis } & \multirow{2}{*}{$\begin{array}{r}\text { Bobot } \\
0,250\end{array}$} & \multirow{2}{*}{$\begin{array}{c}\text { Rating } \\
5\end{array}$} & \multirow{2}{*}{$\begin{array}{l}\text { Skor } \\
1,250\end{array}$} \\
\hline & 1 & $\begin{array}{l}\text { Support dari Pemerintah Daerah dalam } \\
\text { Pengembangan Kopi Liberika }\end{array}$ & & & \\
\hline & 2 & $\begin{array}{l}\text { Adanya Program CSR untuk Pengembangan } \\
\text { Kopi Liberika }\end{array}$ & 0,050 & 4 & 0,200 \\
\hline & 3 & Perhatian Pihak Peneliti dan Akademisi & 0,075 & 4 & 0,300 \\
\hline & 4 & Permintaan Pasar Terus meningkat & 0,200 & 4 & 0,800 \\
\hline \multicolumn{3}{|c|}{ Sub total } & & & 2,550 \\
\hline \multirow{4}{*}{$\begin{array}{l}\stackrel{\pi}{ \pm} \\
\stackrel{己}{E}\end{array}$} & \multicolumn{2}{|c|}{ Faktor strategis } & Bobot & Rating & Skor \\
\hline & 1 & Tingginya Pesaing Kopi di Luar Daerah & 0,200 & 5 & 1,000 \\
\hline & 2 & Konversi Lahan & 0,075 & 4 & 0,300 \\
\hline & 3 & Serangan Hama dan Penyakit & 0,150 & 3 & 0,450 \\
\hline \multicolumn{3}{|c|}{ Sub total } & & & 1,750 \\
\hline \multicolumn{3}{|c|}{ Total } & 1,00 & & 0,800 \\
\hline
\end{tabular}

Sumber: Hasil pengolahan data (2020)

Hasil analisis SWOT pada gerai kopi liberika menunjukkan bahwa gerai kopi liberika berada pada kuadran 1 artinya gerai ini memiliki peluang yang cukup baik untuk terus dikembangkan karena produk ini menjual olahan kopi liberika yang sudah dikenal masyarakat terutama di sekitar lokasi gerai kopi liberika yaitu di kecamatan Betara. Selain itu produk kopi liberika yang dijual memiliki kekuatan dari aspek kualitas dan juga kuantitas yang dimiliki. Fokus strategi pada kuadran 1 ini merupakan strategi yang agresif atau aggresive strategy di mana pada strategi ini gerai kopi liberika dapat memanfaatkan peluang yang ada sehingga terjadi peningkatan produktivitas dari olahan kopi liberika yang dipasarkan. Hal ini sejalan dengan pendapat Rangkuti (2014) yang menyatakan bahwa apabila suatu produk berada pada kuadran 1 maka produk tersebut dapat menggunakan strategi pemasaran aggresive strategy untuk meningkatkan peluang dpengembangan produk dan meningkatkan pendapatan bagi usahanya. Gerai kopi liberika saat ini ini terus memaksimumkan kekuatan secara internal maupun eksternal nya. Berdasarkan analisis dan matriks SWOT yakni berada pada kuadran 1 dimana strategi yang tepat adalah strategi peningkatan secara agresif. Sebelum melakukan analisis SWOT, strategi pemasaran perlu disusun berdasarkan faktor internal dan faktor eksternal dari gerai kopi liberika. Faktor internal dan eksternal diidentifikasi berdasarkan variabel-variabel yang terkait pada kondisi internal dan kondisi eksternal pada gerai kopi liberika. Berdasarkan hasil identifikasi secara internal dan eksternal analisis dilanjutkan dengan mengetahui kekuatan, kelemahan, peluang dan ancaman di gerai kopi liberika. 


\section{Kekuatan (strenghts)}

Kecamatan Betara menjadi Sentra Produksi Kopi Liberika di Provinsi Jambi

Kecamatan Betara merupakan salah satu wilayah di provinsi Jambi yang memiliki iklim dan jenis tanah yang cocok ditanami kopi liberika. Sesuai dengan kondisi iklim dan jenis tanah tersebu, Kecamatan Betara menjadi sentra budidaya kopi liberika di provinsi Jambi. Dilihat dari topografinya, Kecamatan Betara Kabupaten Tanjung Jabung Barat memiliki jenis lahan gambut sehingga cocok ditanami kopi liberika yang tumbuh baik di daerah dataran rendah. Tradisi menanam kopi yang telah puluhan tahun pada masyarakat Betara, kemudian banyaknya kebun kopi liberika khususnya di Kelurahan Mekar Jaya dalam kegiatan pengembangan kopi rantai usaha mulai dari pembibitan, budidaya kopi dalam bentuk perkebunan sampai pada Unit Pengolahan Hasil (UPH) kopi Liberika yang mengolah pasca panen biji kopi liberika merupakan tradisi masyarakat di Kecamatan Betara sebagai mata pencaharian masyarakat yang berprofesi sebagai petani. Kopi liberika bagi masyarakat Kecamatan Betara merupakan salah satu sumber penghasilan yang penting bagi pendapatan rumah tangga petani (Zuhra, 2019). Pendapatan rumah tangga yang berasal dari perkebunan kopi liberika, selanjutnya akan meningkatkan kesejahteraan masyarakat di Kecamatan Betara dan juga di Kabupaten Tanjung Jabung Barat. Selain itu, pendapatan petani kopi liberika, dapat meningkatkan pendapatan asli daerah Kabupaten Tanjung Jabung Barat.

\section{Gerai kopi liberika Mekar Jaya sebagai Tempat Proses Pemasaran dan Promosi}

Gerai kopi liberika Kopi Liberika di Kelurahan Mekar Jaya merupakan suatu bentuk tindakan lanjutan dari CSR Perusahaan PetroChina International Jabung Ltd yang berorientasi kepada program Sustainable Agriculture yang metitik fokuskan kopi Liberika sebagai objek sasaran di Desa Mekar Jaya Kecamatan Betara. Gerai kopi liberika ini menjadi tumpuan sebagai bentuk implementasi keseriusan berjalannya program CSR dalam hal mengembangkan agroindustri kopi Liberika. Gerai kopi liberika memasarkan produk dengan penggunaan gedung yang terbuat dari papan dan kayu yang berbentuk rumah tradisional dan disesuaikan dengan keadaan alam sekitar yang masih banyak areal perkebunan kopi dan pinang namun dikemas dengan konsep yang modern. 


\section{Kopi Liberika Tersertifikasi Indikasi Geografis}

Pada tahun 2015, kopi liberika tungkal komposit terdaftar di Kementerian Hukum dan HAM sebagai Indikasi Geografis dengan No: ID G000000032. Indikasi Geografis untuk kopi liberika tungkal komposit merupakan yang pertama diberikan pada jenis kopi liberika di Indonesia. Dalam hal ini kopi liberika akan menjaga mutu, kualitas dan cita rasa kopi. Masyarakat perlindungan indikasi geografis kopi liberika tungkal komposit atau yang disingkat dengan sebutan MPIG adalah suatu lembaga yang mewakili masyarakat yang mendiami suatu kawasan di Kabupaten Tanjung Jabung Barat yang berkembang karena memiliki visi dan misi yang sama untuk mengadakan, menjaga produksi dan mutu produk liberika tungkal sekaligus untuk menetapkan perlindungan Hak Kekayaan Intelektual (HKI) terhadap produk yang dihasilkan masyarakat dikawasan ini sebagai produk yang memperoleh perlindungan indikasi geografis sehingga diharapkan mampu berdaya saing di pasar domestik maupun di pasar global.

\section{Ketersediaan Bahan Baku}

Ketersediaan bahan baku adalah faktor yang paling utama dalam menentukan keberhasilan pengembangan produk olahan kopi liberika Adapun bahan baku dari olahan kopi liberika adalah biji kopi liberika. Berdasarkan data Dinas Perkebunan Kabupaten Tanjung Jabung Barat tahun 2019 produksi kopi liberika di Kabupaten Tanjung Jabung Barat khususnya di Kecamatan Betara yaitu lebih dari 500 ton dalam satu tahun. Produksi kopi liberika ini menunjukkan bahwa bahan baku olahan kopi liberika cukup tersedia untuk memenuhi permintaan konsumen baik di dalam Kecamatan Betara maupun di luar Kecamatan Betara. Ketersediaan bahan baku dapat menjamin keberlangsungan pemasaran kopi liberika. Apabila bahan baku kopi liberika tersedia dengan baik, maka permintaan konsumen dapat terpenuhi.

\section{Memiliki Sarana dan prasarana penunjang}

Sarana dan prasarana penunjang merupakan bagian yang terpenting dalam proses produksi kopi Liberika. Di Kecamatan Betara khususnya sebagai pusat pengembangan kopi Liberika dari persedian alat-alat yang memadai untuk produksi kopi Liberika seperti mesin pengolah kopi, lantai penjemuran kopi. 


\section{Kelemahan (weakneasses)}

\section{Belum Mampu memenuhi permintaan Pasar}

Sampai saat ini pemasaran Kopi Liberika masih rendah karena belum memiliki strategi untuk memasarkan kopi secara luas. Petani kopi masih belum memiliki kemampuan untuk membaca peluang pasar, kerena kurangnya bimbingan oleh pemerintah. Petani juga memiliki keterbatasan pengetahuan ketika berbicara pemasaran hal ini disebabkan petani juga memikirkan bagaimana proses budidaya kopi yang baik, proses pasca panen, sehingga petani terbatas bagaimana memasarkan dengan kopi dengan baik karena banyak proses yang harus difikirkan oleh petani.

\section{Minimnya Penerapan SOP}

Pengambilan keputusan petani untuk mengolah kopi liberika secara non SOP pada dasarnya didorong terbatasnya pengetahuan, peralatan dan modal yang terbatas serta rendahnya motivasi. Sedangkan petani yang mengolah kopi Liberika secara SOP bertujuan untuk meningkatkan pendapatan. Faktor teknis juga mempengaruhi petani untuk pengolahan pasca panen secara SOP maupun non SOP. Selain itu faktor harga dan keberadaan pedagang pengumpul serta konsumen menjadi acuan petani dalam penentuan proses pengolahan pasca panen.

\section{Penjualan Kopi Liberika dilakukan Individu, belum Bersinergi}

Petani masih bersifat individual dalam memasarkan kopi olahan yang dibuktikan dengan bermunculan brand-brand produk kopi olahan, sehingga terjadi ketatnya persaingan antar petani. Semestinya yang diharapkan kelompok MPIG dapat bekerjasama untuk fokus menjual produk kopi dalam satu brand secara kolektif agar lebih mudah bersaing dengan Arabika dan Robusta. Ditambah lagi efek dari individualitas petani mengakibatkan petani tidak bisa menerima permintaan dalam jumlah besar dikarenakan ketidakmampuan kapasitas produksi perorangan.

\section{Keterbatasan Modal Petani}

Modal adalah faktor yang penting dalam menjalankan suatu usaha. Modal juga sangat dibutuhkan dalam pengembangan produk maupun pemasaran hasil produksi kopi liberika. Terlihat pada analisis data di lapangan, petani kopi liberika menghadapi keterbatasan modal. Keterbatasan modal ini menyebabkan terjadinya penurunan kuantitas dan kualitas hasil kopi liberika yang diproduksi oleh petani. Budidaya kopi liberika di kecamatan Betara sangat tergantung dengan kondisi alam. 
Kegagalan panen yang dialami oleh petani kopi liberika menjadi permasalahan yang sangat penting untuk diselesaikan. Hal ini juga berkaitan dengan kurangnya kesadaran petani untuk menggunakan pupuk dan obat-obatan untuk mencegah terjadinya kegagalan panen tersebut. Kurangnya pemahaman Petani dalam menggunakan pupuk dan obat-obatan dikarenakan adanya keterbatasan modal yang dimiliki oleh petani. Peranan modal bukan hanya dilihat dari hubungannya dengan penggunaan pupuk dan obat-obatan saja tetapi juga modal digunakan dalam pembelian dan penentuan bibit yang digunakan, sarana produksi lainnya yakni peralatan dan teknologi panen dan pasca panen.

\section{Peluang (opportunities)}

\section{Dukungan dari Pemerintah Daerah dalam Pengembangan Kopi Liberika}

Pengembangan kopi liberika sangat bergantung kepada mitra yang terkait. Salah satu mitra yang paling utama dalam memberikan dukungan yaitu pemerintah daerah. Dalam kegiatan pemasaran kopi liberika, pemerintah daerah berperan sebagai koordinator dan fasilitator dalam pengembangan kopi liberika terutama dalam kegiatan pemasarannya. Selain itu, pemerintah daerah ah juga melibatkan berbagai lembaga dan instansi pemerintahan yang berada di bawah tanggung jawab pemerintah daerah tersebut, dunia usaha dan masyarakat sebagai konsumen dalam menyusun rencana dan strategi sehingga mampu meningkatkan konsistensi pengembangan usaha kopi liberika terutama pengembangan gerai kopi liberika di Kecamatan Betara. Pemerintah juga terlibat mempromosikan kopi liberika kepada investor luar daerah dan juga giat memperkenalkan kopi liberka event-event atau pameran kopi di skala nasional dan internasional.

\section{Adanya Program CSR unruk Pengembangan Kopi Liberika}

Program CSR atau tanggung jawab perusahaan secara sosial adalah suatu kegiatan atau tindakan yang dilakukan oleh perusahaan atau unit usaha sebagai bentuk tanggung jawab perusahaan bagi kondisi sosial dan ekonomi di lingkungan sekitar perusahaan itu berada. Program CSR dapat berupa bantuan barang maupun jasa bagi pengembangan ekonomi suatu wilayah. Pengembangan ekonomi ini bertujuan untuk meningkatkan kesejahteraan masyarakat sekitar perusahaan. Perusahaan yang bermitra dengan gerai kopi liberika adalah PetroChina International Jabung Ltd yang bermitra dengan gerai kopi liberika sejak tahun 2018. Petrochina International Jabung Ltd menginisiasi program-program untuk membantu mengembangkan komoditi kopi di Kecamatan Betara sebagai tanggung jawab sosial untuk masyarakat di sekitar perusahaan. 


\section{Perhatian Pihak Peneliti dan Akademisi}

Akademisi juga merupakan elemen penting didalam keterlibatan program pengembangan kopi liberika. Universitas Jambi menjadi salah satu institusi pendidikan yang sejak awal dilibatkan. LPPM UNJA juga sangat mengapresiasi kegiatan pengembangan kopi Liberika sebagai partisipasi yang aktif. Bahkan pihak UNJA akan mempunyai program khusus pengembangan produk turunan berbasis kopi liberika. Kopi liberika dan Program pengembangan kopi liberika juga mengundang minat akademisi UNJA baik Mahasiswa dan pengajarnya untuk melakukan penelitian lebih spesifik maupun kolaborasi lintas fakultas.

\section{Permintaan Pasar Terus meningkat}

Menurut data Survei SUSENAS BPS, konsumsi kopi di Indonesia mulai meningkat 8,25 persen per kapita dari 2017 ke 2018. Bahkan konsumsi per kapita diprediksi stabil di kisaran 0,864 kg pada 2019-2020 dari 0,798 $\mathrm{kg}$ pada 2017.Hal Ini tidak mengherankan lantaran menjamurnya budaya kultur kedai kopi di Indonesia, khususnya di Provinsi Jambi. Berbagai kedai kopi tersebut bersaing menjual kopi dari Arabika, Robusta dan Liberika. Pelaku usaha kopi cukup beragam.

\section{Ancaman (threats)}

\section{Tingginya Pesaing Kopi di Luar Daerah}

Semakin meningkatnya trend kopi, banyak daerah yang mengusahakan Kopi dengan jenis Arabika dan Robusta. Dengan sistem dan manajemen yang lebih baik, sehingga pelaku usaha tersebut mampu memproduksi kopi liberika yang memiliki kualitas dan kuantitas yang baik. Kopi liberika masih dalam tahap pengembangan sehingga belum mampu mengimbangi pasar kopi yang sudah melekat dan lebih familiar di kalangan konsumen kopi. Belum lagi pasar kopi Liberika belum terjamin karena belum pastinya jumlah produksi yang dapat dihasilkan oleh petani sehingga petani kopi liberika belum mampu memenuhi permintaan dalam jumlah banyak.

\section{Konversi Lahan}

Konversi lahan di Kecamatan Betara Kabupaten Tanjung Jabung Barat pada saat ini sangat marak terjadi yang terjadi dikarenakan keinginan dan motivasi sangat rendah untuk mempertahankan lahan usahatani kopi. Hal ini disebabkan karena menurut penuturan petani di lokasi penelitian membutuhkan alat teknologi tinggi, biaya proses produksi yang mahal, serta membutuhkan waktu yang cukup lama 
sedangkan, komoditi lain seperti pinang dan sawit tidak membutuhkan proses pasca panen yang begitu panjang seperti kopi dan lebih praktis karena langsung dijual kepada pedangang pengumpul.

\section{Serangan Hama dan Penyakit pada Tanaman Kopi Liberika}

Kopi liberika di Kecamatan Betara menghadapi beberapa permasalahan terkait budidaya. Salah satu masalah yang dihadapi oleh petani adalah serangan hama dan penyakit yang menyerang tanaman kopi liberika. Serangan hama dan penyakit ini menimbulkan kerugian yang cukup besar bagi petani. Kerugian ini menyebabkan banyaknya petani beralih ke komoditi lain karena hasil produksi yang diterima tidak sebanding dengan korbanan yang dikeluarkan dalam mengelola tanaman kopi liberika. Rendahnya kualitas dan kuantitas produk kopi liberika yang dihasilkan karena serangan hama dan penyakit tersebut akan berpengaruh terhadap kualitas dan kuantitas produk yang diterima oleh konsumen. Permasalahan ini dapat diatasi dengan strategi bersaing dalam bauran pemasaran. Hal ini sejalan dengan penelitian Maulana (2020), Abidin (2017), Jonna (2018) dan Umar (2017) yang menyatakan bahwa dalam marketing mix adalah salah satu strategi bersaing yang perlu dipertahankan adalah strategi produk. Strategi produk dalam hal ini adalah produk yang inovatif dan sesuai dengan keinginan konsumen konsumen. Produk tersebut harus mampu memenuhi permintaan konsumen. Setiap produsen terutama gerai kopi liberika harus membuat strategi untuk menetapkan posisi gerai kopi liberika lebih kuat dan menutupi kelemahan yang ada.

\section{SIMPULAN DAN SARAN}

\section{Simpulan}

Berdasarkan hasil penelitian, strategi pemasaran yang dianalisis dengan pendekatan marketing mix 7P pada gerai kopi liberika menunjukkan bahwa secara umum gerai kopi liberika sudah menerapkan strategi marketing mix dengan baik. Bahkan ada beberapa indikator yang sesuai dengan harapan konsumen yakni khususnya pada faktor process, selain faktor process ada pada faktor lain akan tetapi hanya beberapa indikator saja pada faktor marketing mix lainnya yaitu, produk yang disukai, lokasi yang strategis, sikap dan perilaku karyawan yang sopan, keramahan karyawan, kenyamanan, dan penataan produk yang teratur sesuai jenis produk. Pada penelitian ini strategi pengembangan gerai kopi liberika dihasilkan melalui analisis SWOT. Berdasarkan hasil identifikasi faktor internal dan eksternal maka dapat 
diketahui kekuatan (strenght), kelemahan (weakness), peluang (opportunity) dan ancaman (threat) di daerah penelitian.

\section{Saran}

Sejalan dengan hasil penelitian marketing mix dan analisis SWOT, maka produsen harus meningkatkan kualitas kopi robusta yang dihasilkan baik dari aspek budidaya maupun pengolahan.

\section{DAFTAR PUSTAKA}

Abidin, Zainal, M., Mas'udin, I. dan Utama, D. M. 2017. Pemilihan strategi pemasaran dengan metode SWOT dan TOPSIS. Jurnal Teknik Industry. 18(1): 55-67

Abdullah, T dan F. Tantri. 2015. Manajemen Pemasaran. Jakarta: Raja Grafindo Persada

Anderson, E. W. 1994. Customer satisfaction, findings from Sweden market share, and profitability. Journal of Marketing. 58(3): 53-66

Hernanto, F. 1991. Ilmu Usahatani. Jakarta: Penebar Swadaya

Hariyati, Y. dan Sumarno, J. 2013. Pengembangan Agroindustri Pedesaan Berbasis Kopi Menuju Produk Specialty Kabupaten Jember. Lembaga Penelitian Universitas Jember. Laporan Hasil Penelitian Hibah Strategis Nasional.

Jonna, Y. F. 2018. Strategi Pengembangan Usahatani Kopi Liberika (Coffee Liberica) Di Desa Kadarupat Kabupaten Kepulauan Meranti Provinsi Riau. JOM FEB. 1(1): 1-14

Khulud, H. Arifin, Z. (2016). Analisa Pengaruh Bauran Pemasaran Terhadap Volume Ekspor (Studi Dengan Pendekatan Biaya Pada Komoditi Kopi Di PT. Asal Jaya). Jurnal Administrasi Bisnis. 32(2): 53-58

Kotler dan Armstrong. 2001. Prinsip-prinsip Pemasaran. Jakarta : Erlangga.

Marrus. 2002. Manajemen Pelayanan Umum di Indonesia. Jakarta: Penerbit PT. Bumi Aksa.

Maulana, W. 2020. Metode Marketing Mix Dalam Penyusunan Strategi Bersaiing Pada IKM Keripik Tempe Ayudy. Jurnal Perilaku Dan Strategi Bisnis. 8(2): 141-151

Nasution, M. I., Prayogi, M. A. dan Nasution, S. M., A. 2017. Analisis Pengaruh Bauran Pemasaran Terhadap Volume Penjualan. Jurnal Riset Sains Manajemen. 1(1): 1-12

Nurcahyo, F. dan Wahyuati, A. 2016. Pengaruh bauran pemasaran terhadap volume penjualan pada restoran McDonald's Delta Plaza Surabaya. Jurnal Ilmu dan Riset Manajemen (JIRM). 5(4): 20-30

440 | Rozaina Ningsih, Dwi Nurul Amalia; Strategi Pengembangan Kopi... 
Nurman., Susanti, E. dan Agia, N. L. 2020. Strategi Peningkatan Daya Saing Kopi Liberika DI Kabupaten Kepulauan Meranti. COSTING: Journal of Economic, Business and Accounting. 3(2): 499-505.

Retnowati, N. dan Putra, E. 2017. Analisis Strategi Pemasaran Kopi Bubuk PDP Kahyangan di Kabupaten Jember. Seminar Nasional Hasil Penelitian 2017.

Rangkuti, F. 2014. Analisis SWOT : Teknik Membedah Kasus Bisnis. Jakarta : PT. Gramedia pustaka utama.

Sekaran, U. 2006. Research Methods For Business. Jakarta: Salemba Empat

Soekartawi. 2011. Ilmu Usahatani dan Penelitian untuk Pengembangan Petani Kecil. Jakarta: Penerbit UI.

Umar, Z. A. 2012. Strategi Bauran Pemasaran dalam Meningkatkan Volume Penjualan Ikan Tuna Olahan pada PT. Betel Citra Seyan Gorontalo. Jurnal INOVASI. 9(1): 1-26.

Suratiyah, K. 2009. Ilmu usahatani. Jakarta: Penerbit Penebar Swadaya.

Waluyo, E. dan Nurliam, A. 2017. Potensi Pengembangan Kopi Liberika (Coffea liberica) Pola Agroforestry dan Prospek Pemasarannya untuk Mendukung Restorasi Lahan Gambut di Sumatera. Palembang. Prosiding Seminar Nasional Lahan Suboptimal 2017.

Zeithaml, V. 1988. Consumer Perceptions: A Means-End Model And Synthesis Of Evidence Of Price, Quality And Value. Journal of Marketing. 52(3): 122.

Zuhra, H. S. dan Anis, T. M, 2019. Pengembangan Usahatani Kopi Liberika Berbasis Indeks Keberlanjutan Di Kecamatan Betara Kabupaten Tanjung Jabung Barat. Jurnal Pembangunan Berkelanjutan. 2(1): 89-101. 